\title{
The Analysis of the Relationship between Well Being and the Levels of Emotional Abuse of the Teacher Candidates Perceive
}

\author{
Zuleyha Sakar ${ }^{1}$, Figen Akca $^{1} \&$ Aysegul Bozkurt ${ }^{1}$ \\ ${ }^{1}$ Faculty of Education, Uludağ University, Bursa, Turkey \\ Correspondence: Zuleyha Sakar, Bursa Courthouse Ataevler Additional Service Building, Bursa, Turkey. Tel: \\ 90-554-256-3699. E-mail: sakarzuleyha@gmail.com
}

Received: November 17, 2016

Accepted: January 3, $2017 \quad$ Online Published: February 16, 2017

doi:10.5539/jel.v6n2p272

URL: http://doi.org/10.5539/jel.v6n2p272

\begin{abstract}
Emotional abuse can be defined as a large behavior pattern which the individual is exposed to and can be compiled as, the abasement, violent attitude, exclusion, continuous criticism, unfulfilled need for love and making someone feel worthless. From this point of view the effect on the well being is a key concern about the individuals exposed to emotional abuse. Accordingly the purpose of this study is determined as to analyze of the relationship between the level of emotional abuse and well being of teacher candidates perceive. For this purpose 438 teacher candidates, who study at the Faculty of Education in Uludağ University, were utilized in the study. In the research descriptive method was used and the data was obtained by "Perceived Emotional Abuse Scale" (Ersanll, Y1lmaz, \& Özcan, 2013) and "Psychological Well Being Scale" (Telef, 2013). According to the findings obtained in order to determine the relationship between the psychological well being and the emotional abuse that teacher candidates perceive, correlation and simple linear regression analysis were performed and it is found that there is a significant negative relation in between $(p<.01)$. In addition in terms of the variables of gender, developmental period they are in, department and the level of academic success they perceive, it is discovered that the levels of perceived emotional abuse predict their psychological well being between $12 \%$ and $24 \%$.
\end{abstract}

Keywords: emotional abuse, well being, teacher candidate

\section{Introduction}

The word meaning of abuse is "utilization, employment, to take advantage of something, exploitation" (Türkçe Sözlük, 2005, p. 991). Abuse is the violation of fundamental rights and freedoms of individuals. In a wide range of conditions from emotional abuse to sexual abuse and from rape to torture, physical and mental disorder even loss of life can emerge (Arslan, 2015).

Emotional abuse is the exposure of a child or an adolescent to humiliating and insulting comments, to verbal threats that would put his or her emotional or mental health into danger (Zoroğlu et al., 2001; Şimşek, Cenkseven, $\&$ Önder, 2011). Emotional abuse not only can be seen solely but can be accompanied with other physical and sexual abuse types as well. The effects of emotional abuse can continue even after the effects of physical and sexual abuse disappear (Polat, 2001; Katz \& Arias, 1999). In this sense emotional abuse is considered as a distinguishing state which is at the center of all types of abuse (Iwaniec, Larkin, \& Higgins, 2006).

One of the most significant characteristics that distinguish emotional abuse from other abuse types is the fact that it is accepted as "ordinary" by the social and the cultural environments, which makes it more difficult to perceive it as a kind of abuse. The fact that emotional abuse is not as provable as physical and sexual abuse is one of the most important reasons why it is ignored (Ersanlı et al., 2013). Because of all these reasons explicit data cannot be reached about the prevalence of emotional abuse (Soysüren-Yaşar, 2009).

Ryan and Deci (2001) suggested two general points of views as subjective well being and psychological well being (cited by Telef, Uzman, \& Ergün, 2012). The concept of subjective well being can be defined being content with life, the plentitude of positive emotions and low negative affection (Hafferon \& Boniwell, 2014; Tuzgöl Dost, 2007). According to Ryff and Keyes (1995) the concept of psychological well being is expressed as owning life purposes, accomplish potentials, the quality of the relationships built and feeling responsible about life. There are six dimensions in psychological well being model of Ryff (1989); they are self-acceptance 
(positive evaluation of the individual's own life and self), life purpose, personal development, positive relations with others, environmental control (the capacity of guiding their own and environment of the individuals) and autonomy (cited Telef, 2013; Sezer, 2013). Forgeard et al. (2011) described psychological well being as well living and doing good deeds rather than feeling good.

The social structure of school takes an important role in terms of the studies regarding supervising and observing students' behavior and the frequency and diversity of the peer abuse problems. It is quite difficult for administrators and teachers to have total control over the personal and domestic factors that can cause peer abuse. However it seems more possible to increase supervision, take necessary precautions and change the school atmosphere in order to decrease peer abuse. The role of the teacher is incontrovertibly important in the emergence of the teacher sourced disruptive behaviors. The fact that inability of the teacher is an important element in the emergence of the disruptive behavior in student (Yüksel \& Ergün, 2005; Çelikkaleli, Balcı, Çapri, \& Büte, 2009), also the personal characteristics, lack of self-confidence, level of burnout, fear of failure, dislike for children and some private problems of the teacher, may be the reason for the discipline problems in the classroom is asserted by Temel (2005), Tertemiz (2001) and Erden (2005). DiLalla and Mullineaux (2007) suggested that the children who have disruptive behaviors tend to argue with their teachers more often and the teachers have negative relationships with these children.

When the literature is searched, teachers' being one of the most important members of the education environment is a phenomenon accepted by everyone. In order to create an effective teaching environment teachers are expected to have a well mood and a high psychological well being, they should be looking at the future with hope and be purified from their affective/emotional difficulties as much as possible. For this purpose gender, developmental periods, department and the perceived academic success variables, which are thought to foresee the emotional abuse that teacher candidates perceive and considered to be related with their psychological well being, were included within the scope of the research.

\subsection{For this Purpose Responses Are Searched for These Questions}

1) Is there a connection between the level of the emotional abuse teacher candidates perceived and their psychological well being according to gender variable?

2) Is there a connection between the level of the emotional abuse teacher candidates perceived and their psychological well being in terms of the developmental periods?

3) Is there a connection between the level of the emotional abuse teacher candidates perceived and their psychological well being according to department variable?

4) Is there a connection between the level of the emotional abuse teacher candidates perceived and their psychological well being in terms of perceived academic success?

5) To what extent do the levels of perceived emotional abuse teachers predict their psychological well being in terms of gender, developmental period they are in, their branch and the academic success variables they perceived?

\section{Method}

\subsection{Research Model}

This research is qualitative and performed in the relational scanning model. This model aims to determine the existence of a change in the unity between two or more variables and the degree of this change (Arlı \& Nazik, 2001; Büyüköztürk, 2015; Ünver, Gamgam, \& Altunkaynak, 2011).

\subsection{The Study Group}

The sample of the research consists of 438 teacher candidates (undergraduate, pedagogical formation level) who study at Uludağ University in the $2015-2016$ academic year. $73 \%$ of the teacher candidates that participate in the research are female, and $27 \%$ of them are male. $76 \%$ of the candidates are in the emerging adulthood period and $24 \%$ of them are in the adulthood period. Apart from that $24 \%$ of the participators study at the Education of Religion and Ethics undergraduate program and $18 \%$ of them at Psychological Counseling and Guidance program and the rest $58 \%$ study at the other social sciences programs or in departments that accept students with aptitude tests. $29 \%$ of the teacher candidates that participated in the research perceive their academic success as high, $67 \%$ perceive as medium and $7 \%$ of them perceive their academic success as low. The teacher candidates who perceive their academic success as low were not included in the statistical process. The teacher candidates were instructed as required and on a volunteer basis Perceived Emotional Abuse Scale and Psychological Well Being Scale were applied. 


\subsection{Research Instruments}

\subsubsection{Perceived Emotional Abuse Scale}

Perceived Emotional Abuse Scale was developed by Ersanlı et al. (2013). The scale is 5 point likert type scale and the ranking is in this way (5) Completely agree (4) Agree (3) Indifferent (2) Disagree (1) Completely Disagree. 3 positive and 58 negative items constitute the scale. In the reliability study of the scale internal consistency coefficient was $\alpha=.95$ and test retest consistency coefficient was found $\mathrm{r}=.76$ (Ersanli et al., 2013).

\subsubsection{Psychological Well Being Scale}

Psychological Well Being Scale was developed by Diener et al. (2009) and adapted to Turkish by Telef (2013). For the validity studies of the scale, exploratory factor analysis, confirmatory factor analysis and similar scale validity studies were done. For the reliability study Cronbach alpha coefficient was .80 and test retest correlation coefficient was evaluated as $\mathrm{r}=.86$ (Telef, 2013).

Through the personal information form, prepared for taking demographic information of the participants, information regarding gender, developmental period they are in, undergraduate program they study and academic success was taken from teacher candidates.

\section{Results}

In this part of the study we analyzed whether there is relationship between psychological well being and perceived emotional abuse levels of teacher candidates with Pearson Correlation Analysis. The results are below.

Table 1. The results of the correlation analysis between the psychological well being and perceived emotional abuse levels of teacher candidates according to the gender variable

\begin{tabular}{|c|c|c|c|c|c|c|}
\hline Gender & & & & $\begin{array}{l}\text { Perceived } \\
\text { Abuse }\end{array}$ & Emotional & Psychological Well Being \\
\hline \multirow{11}{*}{$\begin{array}{l}\text { Female } \\
\text { Candidates }\end{array}$} & \multirow{7}{*}{ Teacher } & & & & & $-.452 *$ \\
\hline & & & Pearson Correlation & 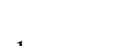 & & \\
\hline & & Perceived Emotional Abuse & Sig. (2-tailed) & & & .000 \\
\hline & & & $\mathrm{N}$ & 321 & & 321 \\
\hline & & & Pearson Correlation & $-.452^{*}$ & & 1 \\
\hline & & Psychological Well Being & Sig. (2-tailed) & .000 & & \\
\hline & & & $\mathrm{N}$ & 321 & & 321 \\
\hline & & & & $\begin{array}{l}\text { Perceived } \\
\text { Abuse }\end{array}$ & Emotional & Psychological Well Being \\
\hline & & & Pearson Correlation & 1 & & $-.466^{*}$ \\
\hline & & Perceived Emotional Abuse & Sig. (2-tailed) & & & .000 \\
\hline & \multirow{4}{*}{ Teacher } & & $\mathrm{N}$ & 117 & & 117 \\
\hline \multirow{3}{*}{$\begin{array}{l}\text { Male } \\
\text { Candidates }\end{array}$} & & & Pearson Correlation & $-.466^{*}$ & & 1 \\
\hline & & Psychological Well Being & Sig. (2-tailed) & .000 & & \\
\hline & & & $\mathrm{N}$ & 117 & & 117 \\
\hline
\end{tabular}

When the Table 1 is analyzed it is seen that there is a significant negative relationship at medium level between psychological well being and emotional abuse the teacher candidates perceive (for the female $r=-0.452, p<.001$ and for the male $\mathrm{r}=-0.466, \mathrm{p}<.001$ ). According to this it can be said that as long as the levels of emotional abuse that female and male teacher candidates perceive increase, their psychological well being decreases. 
Table 2. The results of the correlation analysis between the psychological well being and perceived emotional abuse levels of teacher candidates according to the developmental period variable

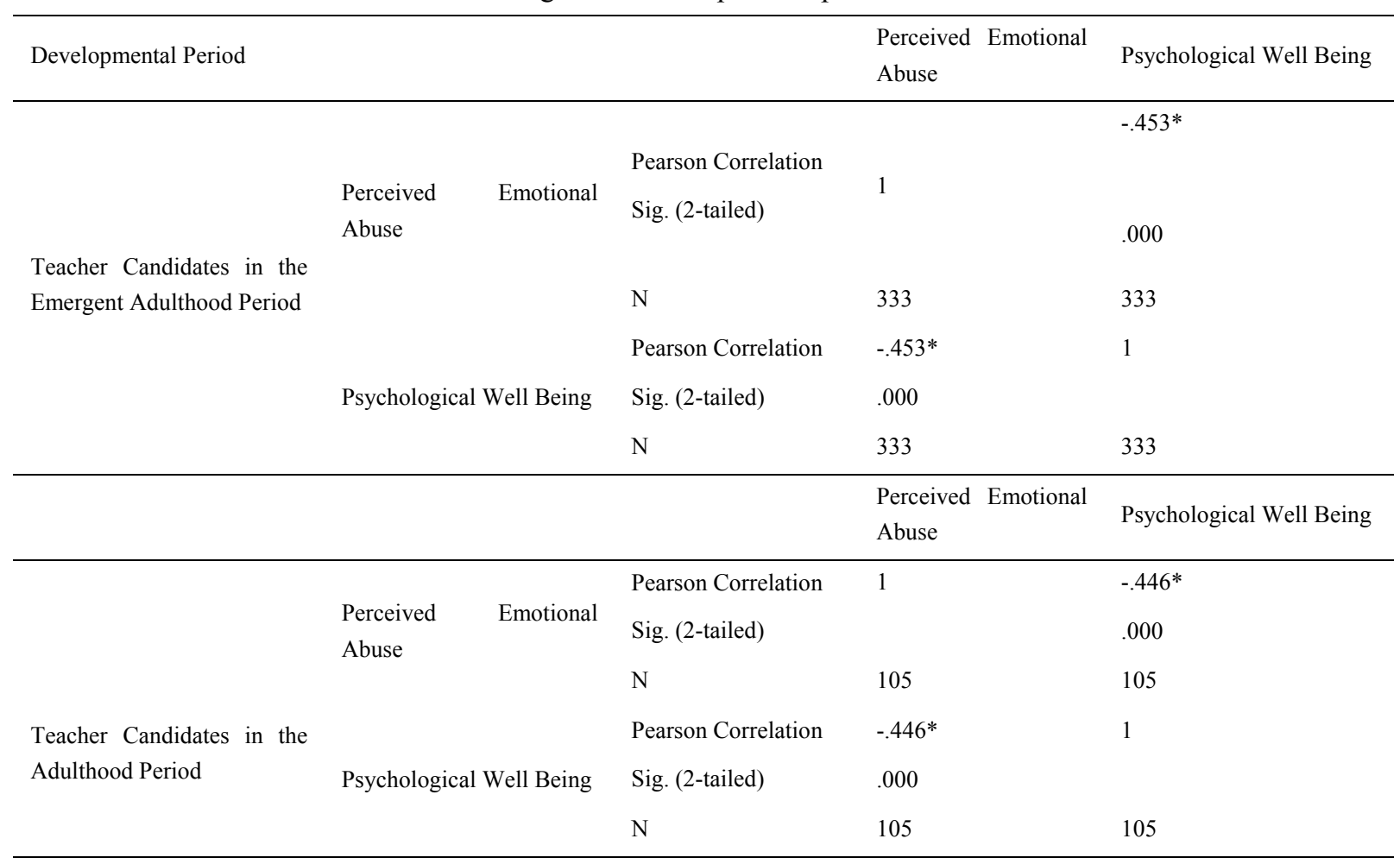

$* \mathrm{p}<.001$.

When the Table 2 is analyzed it is seen that there is a significant negative relationship at medium level between psychological well being and emotional abuse the teacher candidates who are from the emergent adulthood and adulthood periods perceive (for the emergent adulthood $\mathrm{r}=-0.453, \mathrm{p}<.001$ and for adults $\mathrm{r}=-0.446, \mathrm{p}<.001$ ). According to this it can be said that as long as the levels of perceived emotional abuse of the teacher candidates from emergent adulthood and adulthood period increase their psychological well being decreases.

Table 3. The results of the correlation analysis between the psychological well being and perceived emotional abuse levels of teacher candidates according to the department variable

\begin{tabular}{|c|c|c|c|c|}
\hline Undergraduate Program & & & $\begin{array}{l}\text { Perceived Emotional } \\
\text { Abuse }\end{array}$ & Psychological Well Being \\
\hline \multirow{6}{*}{$\begin{array}{l}\text { Counseling } \\
\text { Candidates }\end{array}$} & $\begin{array}{l}\text { Perceived } \\
\text { Abuse }\end{array}$ & $\begin{array}{l}\text { Pearson Correlation } \\
\text { Sig. (2-tailed) }\end{array}$ & 1 & $\begin{array}{l}-.358 * \\
.000\end{array}$ \\
\hline & \multirow{5}{*}{ Psychological Well Being } & $\mathrm{N}$ & 79 & 79 \\
\hline & & Pearson Correlation & $-.358^{*}$ & 1 \\
\hline & & Sig. (2-tailed) & .000 & \\
\hline & & $\mathrm{N}$ & 79 & 79 \\
\hline & & & $\begin{array}{l}\text { Perceived Emotional } \\
\text { Abuse }\end{array}$ & Psychological Well Being \\
\hline $\begin{array}{l}\text { Teacher Candidates of } \\
\text { Education of Religion and } \\
\text { Ethics }\end{array}$ & $\begin{array}{l}\text { Perceived } \\
\text { Abuse }\end{array}$ & $\begin{array}{l}\text { Pearson Correlation } \\
\text { Sig. (2-tailed) } \\
\mathrm{N}\end{array}$ & 106 & $\begin{array}{l}-.475^{*} \\
.000 \\
106\end{array}$ \\
\hline
\end{tabular}




\begin{tabular}{|c|c|c|c|c|}
\hline & \multirow[b]{2}{*}{ Psychological Well Being } & Pearson Correlation & $-.475^{*}$ & 1 \\
\hline & & Sig. (2-tailed) & .000 & \\
\hline & & $\mathrm{N}$ & 106 & 106 \\
\hline & & & $\begin{array}{l}\text { Perceived Emotional } \\
\text { Abuse }\end{array}$ & Psychological Well Being \\
\hline \multirow{6}{*}{$\begin{array}{l}\text { Teacher Candidates } \\
\text { Other Departments }\end{array}$} & \multirow{3}{*}{$\begin{array}{l}\text { Perceived } \\
\text { Abuse }\end{array}$} & Pearson Correlation & 1 & $-.490 *$ \\
\hline & & Sig. (2-tailed) & & .000 \\
\hline & & $\mathrm{N}$ & 253 & 253 \\
\hline & \multirow{3}{*}{ Psychological Well Being } & Pearson Correlation & $-.490 *$ & .000 \\
\hline & & Sig. (2-tailed) & .000 & \\
\hline & & $\mathrm{N}$ & 253 & 253 \\
\hline
\end{tabular}

$* \mathrm{p}<.001$.

When the Table 3, in which the relationship between the points that teacher candidates that study education of religion and ethics and other departments took from the scales, is analyzed it is seen that there is a significant negative relationship at medium level between psychological well being and perceived emotional abuse of the teacher candidates (for counseling teacher candidates $\mathrm{r}=-0.358, \mathrm{p}<.001$, and for education of religion and ethics teacher candidates $r=-0.475, p<.001$ and for the candidates in other departments $r=-0.490, p<.001$ ). According to these values it can be said that as long as the levels of perceived emotional abuse that teacher candidates from all departments increase, their psychological well being decreases.

Table 4. The results of the correlation analysis between the psychological well being and perceived emotional abuse levels of teacher candidates according to the academic success variable

\begin{tabular}{|c|c|c|c|c|c|}
\hline $\begin{array}{l}\text { Perceived Academic } \\
\text { Success }\end{array}$ & & & $\begin{array}{l}\text { Perceived } \\
\text { Abuse }\end{array}$ & Emotional & Psychological Well Being \\
\hline \multirow{7}{*}{$\begin{array}{l}\text { Teacher Candidates } \\
\text { with High Academic } \\
\text { Success }\end{array}$} & \multirow{3}{*}{ Perceived Emotional Abuse } & Pearson Correlation & \multirow{2}{*}{1} & & $-.429 *$ \\
\hline & & Sig. (2-tailed) & & & .000 \\
\hline & & $\mathrm{N}$ & 130 & & 130 \\
\hline & \multirow{3}{*}{ Psychological Well Being } & Pearson Correlation & $-.429 *$ & & 1 \\
\hline & & Sig. (2-tailed) & .000 & & \\
\hline & & $\mathrm{N}$ & 130 & & 130 \\
\hline & & & $\begin{array}{l}\text { Perceived } \\
\text { Abuse }\end{array}$ & Emotional & Psychological Well Being \\
\hline \multirow[b]{3}{*}{$\begin{array}{l}\text { Teacher Candidates } \\
\text { with Medium }\end{array}$} & \multirow{3}{*}{ Perceived Emotional Abuse } & Pearson Correlation & 1 & & $-.441 *$ \\
\hline & & Sig. (2-tailed) & & & .000 \\
\hline & & $\mathrm{N}$ & 296 & & 296 \\
\hline \multirow{3}{*}{ Academic Success } & \multirow{3}{*}{$\begin{array}{l}\text { Psychological } \\
\text { Well Being }\end{array}$} & Pearson Correlation & $-.441^{*}$ & & 1 \\
\hline & & Sig. (2-tailed) & .000 & & \\
\hline & & $\mathrm{N}$ & 296 & & 296 \\
\hline
\end{tabular}

$* \mathrm{p}<.001$. 
With the analysis of the Table, in which the points that the teacher candidates who participated in the research and expressed their academic success as high and medium, took from the scales, it is seen that there is a significant negative relationship at medium level between the levels of perceived emotional abuse and psychological well being (for high academic success $r=-0.429$, for medium academic success $r=-0.441, p<.001$ ). According to these values it can be said that as long as the levels of perceived emotional abuse of teacher candidates, who express their academic success as high and medium, increase, their psychological well being decreases.

When the data obtained from the tables is analyzed, since a relationship is detected among the variables, in this part of the research Simple Linear Regression Analysis was performed and data obtained is given below.

Table 5. The results of the simple linear regression analysis between the psychological well being and perceived emotional abuse levels of teacher candidates according to the gender variable

\begin{tabular}{llllllllll}
\hline & Predictor Variable & $\mathrm{R}$ & $\mathrm{R}^{2}$ & $\mathrm{~F}$ & $\mathrm{~B}$ & $\mathrm{Sh}$ & $\beta$ & $\mathrm{t}$ & $\mathrm{P}$ \\
\hline $\begin{array}{l}\text { Female Teacher } \\
\text { Candidates }\end{array}$ & $\begin{array}{l}\text { Perceived } \\
\text { Emotional Abuse }\end{array}$ & .452 & .204 & 81.942 & -.741 & .082 & -.452 & -9.052 & .000 \\
\hline & Predictor Variable & $\mathrm{R}$ & $\mathrm{R}^{2}$ & $\mathrm{~F}$ & $\mathrm{~B}$ & $\mathrm{Sh}$ & $\beta$ & $\mathrm{t}$ & $\mathrm{P}$ \\
\hline $\begin{array}{l}\text { Male Teacher } \\
\text { Candidates }\end{array}$ & $\begin{array}{l}\text { Perceived } \\
\text { Emotional Abuse }\end{array}$ & .466 & .217 & 31.822 & -.660 & .117 & -.466 & -5.641 & .000 \\
\hline
\end{tabular}

${ }^{*} p<.001$.

When Table 5 is analyzed it is seen that there is a significant relationship between psychological well being and emotional abuse that female teacher candidates perceive $(\mathrm{R}=.452, \mathrm{p}<.001)$. The perceived emotional abuse explains $20 \%$ of psychological well being of the female teacher candidates. The perceived emotional abuse of female teacher candidates predicts psychological well being at a significant level and negative direction $(\beta=-.452$, $\mathrm{p}<.001)$.

As the Table is analyzed it is seen that there is a significant relationship between psychological well being and emotional abuse the male teacher candidates perceive $(\mathrm{R}=.466, \mathrm{p}<.001)$. The perceived emotional abuse explains $21 \%$ of the psychological well being of the male teacher candidates. The perceived emotional abuse predicts psychological well being of male teacher candidates at a significant level and negative direction.

Table 6. The results of the simple linear regression analysis between the psychological well being and perceived emotional abuse levels of teacher candidates according to the developmental period variable

\begin{tabular}{llllllllll}
\hline & Predictor Variable & $\mathrm{R}$ & $\mathrm{R} \mathrm{R}^{2}$ & $\mathrm{~F}$ & $\mathrm{~B}$ & $\mathrm{Sh}$ & $\beta$ & $\mathrm{t}$ & $\mathrm{P}$ \\
\hline $\begin{array}{l}\text { Teacher Candidates in the } \\
\text { Emergent Adulthood Period }\end{array}$ & $\begin{array}{l}\text { Perceived } \\
\text { Emotional Abuse }\end{array}$ & .453 & .205 & 85.598 & -.700 & .076 & -.453 & -9.252 & .000 \\
\hline & Predictor Variable & $\mathrm{R}$ & $\mathrm{R}$ & $\mathrm{F}$ & $\mathrm{B}$ & $\mathrm{Sh}$ & $\beta$ & $\mathrm{t}$ & $\mathrm{P}$ \\
\hline $\begin{array}{l}\text { Teacher Candidates in the } \\
\text { Adulthood Period }\end{array}$ & $\begin{array}{l}\text { Perceived } \\
\text { Emotional Abuse }\end{array}$ & .446 & .198 & 25.507 & -.677 & .134 & -.446 & -5.05 & .000 \\
\hline
\end{tabular}

$* \mathrm{p}<.001$.

It is seen that there is significant relationship between the psychological well being and emotional abuse perceived by teacher candidates in the emergent adulthood period $(\mathrm{R}=.453, \mathrm{p}<.001)$. The predictor variable explains $20 \%$ of the psychological well being of teacher candidates in the emergent adulthood period. The perceived emotional abuse predicts the psychological well being of the teacher candidates in the emergent adulthood period at a significant level and negative direction $(\beta=-.453, \mathrm{p}<.001)$.

It is seen that there is a significant relationship between the psychological well being of and the perceived emotional abuse of the teacher candidates in adulthood period $(\mathrm{R}=.446, \mathrm{p}<.001)$. The predictor variable explains $19 \%$ of the psychological well being of the teacher candidates in the adulthood period. The perceived emotional 
abuse predicts the psychological well being of the teacher candidates in the adulthood period at a significant level and negative direction $(\beta=-.446, \mathrm{p}<.001)$.

Table 7. The results of the simple linear regression analysis between the psychological well being and perceived emotional abuse levels of teacher candidates according to the department variable

\begin{tabular}{llllllllll}
\hline & Predictor Variable & $\mathrm{R}$ & $\mathrm{R} \mathrm{R}^{2}$ & $\mathrm{~F}$ & $\mathrm{~B}$ & $\mathrm{Sh}$ & $\beta$ & $\mathrm{t}$ & $\mathrm{P}$ \\
\hline Counseling Teacher Candidates & $\begin{array}{l}\text { Perceived } \\
\text { Emotional Abuse }\end{array}$ & .358 & .128 & 11.351 & -.556 & .165 & -.358 & -3.369 & .001 \\
& Predictor Variable & $\mathrm{R}$ & $\mathrm{R}{ }^{2}$ & $\mathrm{~F}$ & $\mathrm{~B}$ & $\mathrm{Sh}$ & $\beta$ & $\mathrm{t}$ & $\mathrm{P}$ \\
\hline $\begin{array}{l}\text { Teacher Candidates of Education } \\
\text { of Religion and Ethics }\end{array}$ & $\begin{array}{l}\text { Perceived } \\
\text { Emotional Abuse }\end{array}$ & .475 & .225 & 30.239 & -.638 & .116 & -.475 & -5.499 & .000 \\
\hline & Predictor Variable & $\mathrm{R}$ & $\mathrm{R}^{2}$ & $\mathrm{~F}$ & $\mathrm{~B}$ & $\mathrm{Sh}$ & $\beta$ & $\mathrm{t}$ & $\mathrm{P}$ \\
\hline $\begin{array}{l}\text { Teacher Candidates in Other } \\
\text { Departments }\end{array}$ & $\begin{array}{l}\text { Perceived } \\
\text { Emotional Abuse }\end{array}$ & .490 & .240 & 79.371 & -.777 & .087 & -.490 & -8.909 & .000 \\
\hline $\mathrm{p}<.001$. & & & & & & & &
\end{tabular}

It is seen that there is a significant relationship between the psychological well being and the emotional abuse that counseling teacher candidates perceive $(\mathrm{R}=.358, \mathrm{p}<.001)$. The predictor variable explains $12 \%$ of the psychological well being of the counseling teacher candidates. The perceived emotional abuse predicts the psychological well being of the counseling teacher candidates at a significant level and negative direction $(\beta=-.556, p<.001)$.

It is seen that there is a significant relationship between the psychological well being and the emotional abuse perceived by the teacher candidates from Education of Religion and Ethics $(\mathrm{R}=.475, \mathrm{p}<.001)$. The predictor variable explains $22 \%$ of the psychological well being of the teacher candidates of religious education. The perceived emotional abuse predicts the psychological well being of the teacher candidates of religious education at a significant level and negative direction $(\beta=-.475, \mathrm{p}<.001)$.

It is seen that there is a significant relationship between the psychological well being and the emotional abuse perceived by teacher candidates from other departments $(\mathrm{R}=.490, \mathrm{p}<.001)$. The predictor variable explains $24 \%$ of the psychological well being of the teacher candidates study in other departments. The perceived emotional abuse predicts the psychological well being of the teacher candidates in other departments in significant negative direction $(\beta=-.490, \mathrm{p}<.001)$.

Table 8 . The results of the simple linear regression analysis between the psychological well being and perceived emotional abuse levels of teacher candidates according to the academic success variable

\begin{tabular}{lllllllllll}
\hline & & Predictor Variable & $\mathrm{R}$ & $\mathrm{R}^{2}$ & $\mathrm{~F}$ & $\mathrm{~B}$ & $\mathrm{Sh}$ & $\beta$ & $\mathrm{t}$ & $\mathrm{P}$ \\
\hline $\begin{array}{l}\text { Teacher Candidates } \\
\text { High Academic Success }\end{array}$ & with & $\begin{array}{l}\text { Perceived Emotional } \\
\text { Abuse }\end{array}$ & .429 & .184 & 28.945 & -.661 & .123 & -.429 & -5.380 & .000 \\
\hline & & Predictor Variable & $\mathrm{R}$ & $\mathrm{R}^{2}$ & $\mathrm{~F}$ & $\mathrm{~B}$ & $\mathrm{Sh}$ & $\beta$ & $\mathrm{t}$ & $\mathrm{P}$ \\
\hline $\begin{array}{l}\text { Teacher Candidates } \\
\text { Medium Success }\end{array}$ & with & $\begin{array}{l}\text { Perceived Emotional } \\
\text { Abuse }\end{array}$ & .441 & .195 & 70.999 & -.703 & .083 & -.441 & -8.426 & .000 \\
\hline
\end{tabular}

$* \mathrm{p}<.001$.

It is seen that there is a significant relationship between the psychological well being and emotional abuse perceived by the teacher candidates who express their academic success as high $(\mathrm{R}=.429, \mathrm{p}<.001)$. The predictor variable explains $18 \%$ of the psychological well being of the teacher candidates who have high academic success. The perceived emotional abuse predict the psychological well being of the teacher candidates in this group at a significant level negative direction $(\beta=-.429, \mathrm{p}<.001)$. 
It is seen that there is a significant relationship between the psychological well being and emotional abuse perceived by the teacher candidates who express their academic success as medium $(R=.441, p<.001)$. The predictor variable explains $19 \%$ of the psychological well being of the teacher candidates who have medium academic success. The perceived emotional abuse predicts the psychological well being of the teacher candidates in this group at a significant level and negative direction $(\beta=-.441, \mathrm{p}<.001)$.

\section{Discussion}

According to the findings of the research it is confirmed that there is a significant negative relationship between the psychological well being and perceived emotional abuse levels of teacher candidates in terms of all variables in the research. From this point of view it can be said that as long as the perceived emotional abuse levels of teacher candidates increase, their psychological well being decreases. According to Karakuş and Çankaya's (2012) study that analyzed the psychological violence that teachers are exposed, it is found that as long as psychological violence increases, the levels of burnout increase as well and life satisfaction decreases. These findings have the quality to support our research findings.

The fact that there is a significant negative relationship in both female and male teacher candidates in terms of perceived emotional abuse and psychological well being can be interpreted that the gender variable does not make a difference in this way for the candidates who chose teaching as an occupation. It is seen that similar results are obtained in the studies of Totan, Aysan and Bektaş (2010), Cihangir and Çankaya (2009), Coşkun (2004), Berber-Çelik and Odacı (2011), Yetim and Göktaş (2004). The effect of being exposed to emotional abuse created on the individual is equal in both genders which can be attributed to the fact that we have been through the similar processes in terms of emotional development. In the studies of Cemaloğlu and Ertürk (2007), Ocak (2008) it is found that male teachers are exposed to intimidation/mobbing and emotional attack more often than female teachers. Similarly according to Balkıs, Duru, Buluş and Duru (2011) it is discovered that the burnout levels of male teacher candidates is higher than female teacher candidates. Gündoğdu and Yavuzer (2012) determined that the subjective well being of female teacher candidates is higher than male teacher candidates.

It is discovered that there is a significant negative relationship between the levels of perceived emotional abuse and psychological well being of teacher candidates in terms of both the emergent adulthood and the adulthood periods. In order to understand the direction of the relation between them, it is found that as a result of the simple linear regression analysis studies done, to understand the direction of the relation it is determined that perceived emotional abuse explains $20 \%$ of the psychological well being in emergent adulthood and $19 \%$ in adulthood. On the basis of these findings it is seen that the effect of the level of perceived emotional abuse of an adult teacher candidate in the emergent adulthood period on the psychological well being decreases when compared to teacher candidates in adulthood. From this point of view according to the results of the perceived emotional abuse of the teacher candidates, who have formation education, it can be said that they relatively provide control at a more significant level. In Özcan's (2009) study that similar findings regarding adulthood period and perceived emotional abuse were obtained.

It is estimated that there is a significant negative relation at the medium level between the levels of the perceived emotional abuse and psychological well being of teacher candidates. On the basis of these findings it can be said that as long as the level of emotional abuse perceived by all teacher candidates that take place in the study group increases their psychological well being decreases. This finding is not surprising (Ryff \& Keyes, 1995; Hefferon $\&$ Boniwell, 2014). As a result of the studies done in order to understand the direction of the relation in between, it is seen that the perceived emotional abuse explains $12 \%$ of psychological well being in counselor teacher candidates, $22 \%$ of education of religion and ethics teacher candidates and $24 \%$ of the other teacher candidates that take place in the study group. The fact that the variance explained in other teacher candidates that take place in the study group is high indicates that teacher candidates in this group are more sensitive than the other teacher candidates in other fields. Also since they have more naive characteristics emotionally, it is expected that their perceived emotional abuse levels will be higher on their psychological well being (Çeliköz \& Çetin, 2004; Arslan \& Balkis, 2016). The fact that in counselor teacher candidates the levels of perceived emotional abuse explains only $12 \%$ of their psychological well being gives rise to thought that other variables can be more effective on the well being of this group rather than perceived emotional abuse.

In terms of academic success of the candidates who have medium or high success perception, it is discovered that there is a significant negative relationship between the levels of emotional abuse they perceive and their psychological well being. In that vein, Balkıs et al. (2011) determined that there is significant negative relationship between the level of burnout and academic success. The effect of medium or higher level of 
academic success perception on well being is an expected result however it is possible to make a comment as this result decreases the effect of the perceived emotional abuse. Since the number of the teacher candidates who express their academic success as low is not enough for statistical process, a comment cannot be made regarding the perceived emotional abuse of the teacher candidates and psychological well being.

In terms of gender, developmental period they are in, department and academic success variables it is discovered that the levels of the perceived emotional abuse of teacher candidates predict their psychological well being between $12 \%$ and $24 \%$ in unstable rates. On the basis of the findings obtained, in the event of doing a structural equalizing model study adding other probable variables together with the perceived emotional abuse which is realized to effect psychological well being, it is thought that more enlightening information can be reached.

As a constraint of the study in order to determine the relation between the perceived emotional abuse and psychological well being of the teacher candidates, the studies for correlation and simple linear regression analysis were done however statistical process could not be performed upon the differentiations of the results. It is thought that it can be a subject of the proceeding study of this research.

In the light of the results of the research it can be predicted that teacher candidates' psychological well being will increase by doing individual or group studies that will raise awareness regarding the levels of the emotional abuse the teacher candidates perceive.

\section{References}

Arlı, M., \& Nazik, M. H. (2001). Bilimsel araştırmaya giriş̧. Gazi Kitapevi, Ankara.

Arslan, G. (2015). Psikolojik istismar, psikolojik sağlamlık, sosyal bağllık ve aidiyet duygusu arasındaki ilişki. Mehmet Akif Ersoy Üniversitesi Eğitim Fakültesi Dergisi, 36, 47-58.

Arslan, G., \& Balkıs, M. (2016). Ergenlerde duygusal istismar, problem davranışlar, öz-yeterlik ve psikolojik sağlamlık arasındaki ilişki. Sakarya Üniversitesi Eğitim Fakültesi Dergisi, 6, 8-22.

Balkıs, M., Duru, E., Buluş, M., \& Duru, S. (2011). Tükenmişliğin öğretmen adayları arasındaki yaygınlığı, demografik değişkenler ve akademik başarı ile ilişkisi. Pamukkale Üniversitesi Eğitim Fakültesi Dergisi, 29(29), 151-165.

Berber-Çelik, Ç., \& Odacı, H. (2011, September). Kendilik Algısı ve Benlik Saygısının Problemli İnternet Kullanımı Üzerindeki Yordayıc1 Rolü. In 5th International Computer ve Instructional Technologies Symposium.

Büyüköztürk, Ş. (2015). Sosyal bilimler için veri analizi el kitabl: İstatistik, araştırma deseni, SPSS uygulamaları ve yorum (Gözden geçirilmiş yirmi birinci baskı). Ankara: PegemA Yayıncılık.

Çelikkaleli, Ö., Balcı, F. A., Çapri, B., \& Büte, M. (2009). İlköğretim Öğretmenlerinin İstenmeyen Öğrenci Davranışlarının Nedenleri Üzerine Görüşleri. İlköğretim Online, 8(3).

Çeliköz, N., \& Çetin, F. (2004). Anadolu öğretmen lisesi öğrencilerinin öğretmenlik mesleğine yönelik tutumlarını etkileyen etmenler. Milli Ĕgitim Dergisi, 32(162), 136-145.

Cemaloğlu, N., \& Ertürk, A. (2007). Öğretmenlerin maruz kaldıkları yıldırma eylemlerinin cinsiyet yönünden incelenmesi. Türk Ë̆itim Bilimleri Dergisi, 5(2), 345-362.

Cihangir ve Çankaya, Z. (2009). Öğretmen adaylarında temel psikolojik ihtiyaçların doyumu ve iyi olma. Türk Ĕ̌itim Bilimleri Dergisi, 7(3).

Coşkun, H. (2004). Kimlik ölçeğinin bir Türk örnekleminde geçerlik ve güvenirlik çalışması. Türk Psikoloji Yazılarl, 7(14), 49-60.

Diener, E. (Ed.). (2009). New measures of well-being. The Netherlands: Springer, The collected works of Ed Diener.

DiLalla, L. F., \& Mullineaux, P. Y. (2007). The effect of classroom environment on problem behaviors: A twin study. Journal of School Psychology.

Erden, M. (2005). Öğretmenlik mesleğine giriş. İstanbul: Alkım Yayınları.

Ersanlı, K., Yılmaz M., \& Özcan, K. (2013). Algılanan duygusal istismar ölçeği (ADİÖ): Geçerlik ve güvenirlik çalışması. Ondokuz Mayls Üniversitesi Eğitim Fakültesi Dergisi, 32, 147-164.

Forgeard, M. J., Jayawickreme, E., Kern, M., \& Seligman, M. E. P. (2011). Doing the right thing: Measuring wellbeing for public policy. International Journal of Wellbeing, 1, 79-106. 
Gündoğdu, R., \& Yavuzer, Y. (2012). Eğitim fakültesi öğrencilerinin öznel iyi oluş ve psikolojik ihtiyaçlarının demografik değişkenlere göre incelenmesi. Mehmet Akif Ersoy Üniversitesi Eğitim Fakültesi Dergisi, 23, 115-131.

Hefferon, K., \& Boniwell, I. (2014). Pozitif psikoloji-kuram, araştırma ve uygulamalar (T. Doğan çev. Ed.). Ankara: Nobel.

Iwaniec, D., Larkin, E., \& Higgins, S. (2006). Research Review:Risk and Resilince in Cases of Emotional Abuse. Child and Family Social Work, 11, 73-82. https://doi.org/10.1111/j.1365-2206.2006.00398.x

Karakuş, M., \& Çankaya, H. (2012). Öğretmenlerin maruz kaldıkları psikolojik şiddete ilişkin bir modelin sınanması. Hacettepe Üniversitesi Eğitim Fakültesi Dergisi, 42, 225-237.

Katz, J., \& Arias, I. (1999). Psychological Abuse And Depressive Symptoms in Dating Women: Do Different Types of Abuse Have Differential Effects? Journal of Family Violence, 14(3), 281-295. https://doi.org/10.1023/A:1022866400736

Ocak, S. (2008). Öğretmenlerin duygusal taciz (mobbing)'e ilişskin algllarl (Edirne ili örneği). Yüksek Lisans Tezi, Trakya Üniversitesi, Edirne.

Özcan, K. (2009). Yetişkin bireylerin algllanan duygusal istismar düzeyleri. Yüksek Lisans Tezi, Ondokuzmayıs Üniversitesi, Samsun.

Polat, O. (2001). Çocuk ve Siddet. İstanbul: Der Yayınları.

Ryff, C. D., \& Keyes, C. L. M. (1995). The structure of psychological wellbeing revisted. Journal of Personality and Social Psychology, 69(4), 719-727. https://doi.org/10.1037/0022-3514.69.4.719

Sezer, F. (2013). Psikolojik iyi olma durumu üzerine etkili faktörler. NWSA-Education Sciences, 8, 489-504.

Şimşek, S., Cenkseven, \& Önder, F. (2011). Ergenlerde davranış problemlerinin, anne-babadan ve öğretmenlerden algılanan duygusal istismar açısından incelenmesi. İlköğretim Online, 10, 1124-1137.

Soysüren Yaşar, F. (2009). Beden eğitimi öğretmenlerinin sporcu öğrenciler üzerindeki duygusal istismar davranışlarının bazı değişkenler açısından incelenmesi. Yüksek lisans tezi, Mersin Üniversitesi, Mersin.

Telef, B. B. (2013). Psikolojik iyi oluş ölçeği: Türkçeye uyarlama, geçerlik ve güvenirlik çalışması. Hacettepe Üniversitesi Eğitim Fakültesi Dergisi, 28, 374-384.

Telef, B. B., Uzman, E., \& Ergün, E. (2012). Öğretmen adaylarında psikolojik iyi oluş ve değerler arasındaki ilişkinin incelenmesi. Çalışma 21. Eğitim Bilimleri Kongresi'nde sunulmuş bildiri.

Temel, A. (2005). Okulda ve sınıfta disiplin. Gençlik ve Rehberlik Sempozyumu. Haziran, İstanbul.

Tertemiz, N. (2001). Sinıf yönetimi ve disiplin (Küçükahmet \& L. Sınıf Yönetimi, Eds.). Ankara: Nobel Yayincilik.

Totan, T., Aysan, F., \& Bektaş, M. (2010). Öğretmen adaylarının mizaç, karakter ve kimlik özellikleri. İnönü Üniversitesi Eğitim Fakültesi Dergisi, 2(11), 19-43.

Türkçe, S. (2005). Türk Dil Kurumu Yayınları. Ankara.

Tuzgöl Dost, M. (2007). Üniversite öğrencilerinin yaşam doyumunun bazı değişkenlere göre incelenmesi. Pamukkale Üniversitesi Eğitim Fakültesi Dergisi, 22, 132-143.

Ünver, Ö., Gamgam, H., \& Altunkaynak, B. (2011). Temel istatistik yöntemler (Gözden geçirilmiş altıncı baskı). Ankara: Seçkin Yayınları.

Yetim, A. A., \& Göktaş, Z. (2004). Öğretmenin mesleki ve kişisel özellikleri. Kastamonu Eğitim Dergisi, 12(2), 541-550.

Yüksel, A., \& Ergün, M. (2005). Sınıfta İstenmeyen Öğrenci Davranışları ve Çözüm Yolları. Yaşadıkça Eğitim, $88,11-16$.

Zoroğlu, S. S., Tüzün, Ü., Sar, V., Öztürk, M., Eröcal Kora, M., \& Alyanak, B. (2001). Çocukluk Dönemi istismar ve ihmalinin olası sonuçları. Anadolu Psikiyatri Dergisi, 2(2), 69-78. 


\section{Copyrights}

Copyright for this article is retained by the author(s), with first publication rights granted to the journal.

This is an open-access article distributed under the terms and conditions of the Creative Commons Attribution license (http://creativecommons.org/licenses/by/4.0/). 